\title{
An exegetical-theological consideration of the hardening of the Jewish religious leaders' hearts in Mark 3:1-6 ${ }^{1}$
}

Sug-Ho Lee

(University of Pretoria)

\section{ABSTRACT \\ An exegetical-theological consideration of the hardening of the Jewish religious leaders' hearts in Mark 3:1-6}

The goal of this article is to look at the literary-theological function of the Jewish religious leaders hardening in Mark 3:1-6. In this text, the concept of "hardness of heart" is used in order to indicate their continued unbelief and rejection. The hardening may also be signaling their presumed end, namely divine judgment (cf. 12:1-2). Although Jesus proclaims the arrival of the kingdom in his authoritative teaching and miracles, the Jewish religious leaders refuse to Jesus' message, as Pharaoh, whose heart is hardened, refuses to obey God's commend. Just as his hardening and rejection allows the plagues to be multiplied as a great judgment (Ex. 7:3) and the catastrophe at the sea (Ex. 14:4, 8, 14), the Jewish religious leaders' unbelieving rejection by their hardening will allow God's judgment. Thus, with regard to the Jewish religious leaders, the concept of "hardness of heart" identifies their unbelief and hostility. It is not simply innocent incomprehension, but an intended rejection.

\section{INTRODUCTION}

In Mark 1:14-15, the passage ending the prologue and introducing Jesus' ministry, Jesus proclaimed the kingdom of God and called for the people to respond with "repentance and faith in the gospel". Mark 1:16-3:6 demonstrated the arrival of the kingdom in Jesus' authoritative teachings and actions. This section also indicates the two general responses to Jesus' assertion. The enthusiastic response of the disciples who left everything to follow $(1: 16-20 ; 2: 14)$ and the crowd that searched Jesus out (1:32-33, 37, 45; 2:2; 3:7-8), was contrasted with the hostility of the Jewish authorities whose hearts were hardened toward Jesus (3:5-6). Mark has indicated in 2:1-3:6 that they did not want to believe in Jesus' identity, which was

1 This article is based on my doctoral dissertation at the University of Pretoria under supervision of Prof J G van der Watt, Department of New Testament Studies. 
evident from his divine actions. They did not understand the relationship between Jesus' authority and his miracles. Thus, when Jesus announced the forgiveness of a paralytic's sins, they assumed that Jesus was blaspheming (2:7). Due to the hardness of their hearts, the opponents failed to believe through the evidence of Jesus' divine actions, that he was indeed the Son of God (cf. 2:10; 3:5), and they consequently refused him (3:6). The religious leaders whose hearts are hardened refuse to believe in Jesus and kill him on their own volition $(3: 6 ; 12: 12 ; 14: 1-2 ; 15: 1)$. The hardness of heart is the basis of their rejecting Jesus, not the result of his rejecting them.

When comparing with other gospels, it is interesting to note that Mark uses this concept in his Gospel in order to indicate the Pharisees' reaction against Jesus, but that Matthew omits reference to the content of their 'hardness of heart' (cf. Mt 12:13 with Mk. 3:5). On the other hand, Luke uses other terms, "they were filled with fury" (Lk. 14:11) that Mark does not use, in reference to the Pharisees' reaction against Jesus. Mark takes this concept, which was known commonly within the larger New Testament world ${ }^{2}$, and gives it prominence, perhaps for a theological reason, rather than merely noting the usage of "hardness of heart". This article is an attempt to present the literary and theological functions of "hardness of heart” as a particular term in Mark 3:1-6.

\section{LITERARY COMPOSITION AND STRUCTURE}

Mark 1:40-45, where Jesus heals a man with leprosy, serves as an introduction for the passages that follow in 2:1-3:6. "The pericope's specific content involving Jesus' ministry and the Mosaic Law (1:44), helps set the thematic stage for following conflict narratives in 2:13:6 involving issues of the Law” (Guelich 1989:73).

2 The terms in the NT, such as $\sigma \kappa \lambda \eta \rho$ ó$\eta \varsigma, \pi \omega \dot{\rho} \rho \sigma \iota \varsigma$, and $\pi \alpha \chi \dot{v} \nu \omega$ express obduracy when linked with the word $\kappa \alpha \rho \delta i \alpha$. These terms are comparatively rare in the NT. Nevertheless, they occur throughout the Synoptic Gospels (10 times out of the 26 occurrences in the NT), particularly in Mark (5 times). They occur 4 times in Acts, 6 times in Paul, 4 times in Hebrews, and once each in

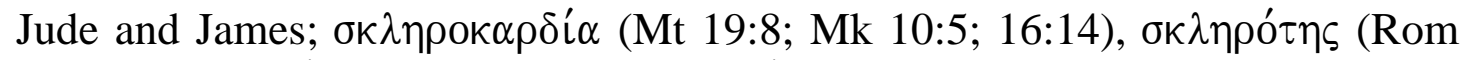

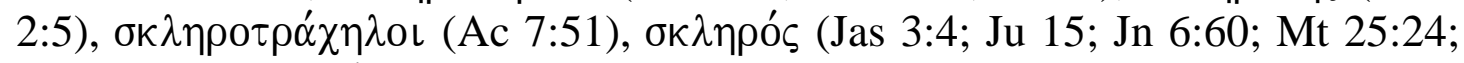

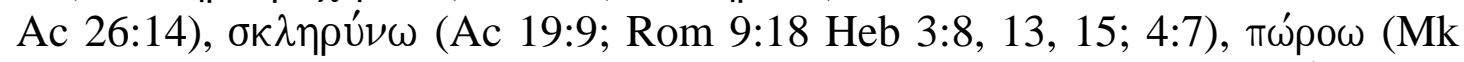

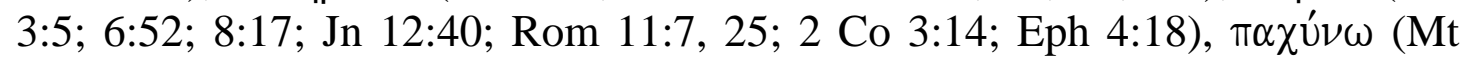
13:15; Ac 28:27). 
The section from Mark 2:1-3:6 contains five controversial stories (the healing of the paralytic, the eating with tax collectors and sinners, the question about fasting, plucking grain on the Sabbath, and the man with the withered hand). In the Markan Public Debate, Dewey (1973:394-401) examines in detail how the rhetorical form of this section (2:1-3:6) serves to underscore the nature and shape of the authorities' unbelief. She indicates a "tight and well-worked-out concentric and chiastic structure," which she represents in the following way:

\section{A 2:1-12 The healing of the paralytic}

\section{B 2:13-17 The call of Levi/eating with sinners}

C 2:18-22 The saying on fasting and on the old and the new

B' 2:23-27 Plucking grain on the Sabbath

\section{A' 3:1-6 The healing on the Sabbath}

Mark himself has gathered these stories in order to indicate how Jesus' authority was rejected by his opponents. His insistence of the authority leads to his rejection and ultimately to his death, a fate foreshadowed in 2:20 and 3:6 (Hooker 1991:83). J Marcus (2000:214) rightly indicates that even more important is a linear development of opposition in the controversial story in which the Jewish religious leaders first question Jesus silently (2:7), then question his disciples about him (2:16), then question Jesus about his disciples' behavior $(2: 18,24)$, then seek a legal reason for condemning him (3:2), then plot his murder (3:6). The final note of the Pharisees' intention to exempt Jesus from the increasing effect of his action emphasizes the close connection between Jesus' activity and his ultimate death. Mark is probably using this collection, "to show how the authority of Jesus was rejected by the Jewish authorities.... [I]t is this refusal to accept Jesus' authority which leads to his rejection and ultimately to his death, a fate foreshadowed in 2:20 and 3:6. This chapter, therefore, is not simply a collection of 'conflict stories' but a demonstration of Jesus' authority and the refusal of Jewish religious authorities to recognize it" (Hooker 1991:83). From the first to the fifth controversial stories (2:1-3:6), the opponents' unbelief, stemming from the hardness of their hearts, appears as hostility toward Jesus, which gradually escalates and intensifies (Rhoads \& Michie 1999:53).

For the reader/hearer, the linear progression of the controversial stories in 2:1-3:6 combines with 'the circular 
progression' to increase the tension and to constitute a climax in the final story (Rhoads \& Michie 1999:53). Furthermore, the fact that the hostility in 3:1-6 is information given to the reader/hearer alone and not to the internal actor of Mark's Gospel (Via 1975:149), indicates that a major function of 3:1-6 is to make the reader/hearer aware of the Jewish religious leaders' insensitivity and incredulity (Dewey 1980:118). The conclusion in 3:5-6 is used as an ending of the story of the withered hand, the total controversy section, and the first stage of Jesus' Galilean ministry. Thus, Mark employed the controversial stories theologically to indicate that Jesus and his opponents are on a collision course that will culminate in Jesus' death (Dewey 1980:119).

Despite its wide-raging structural parallels with the first story in the section 2:1-12, our concluding narrative (3:1-6) is more thoroughly saturated with the element of conflict, as befits its position at the end of the controversy section (Marcus 2000:250). In the course of the passage, one sees from the side of Jesus, provocative behavior (3:3), anger, and sorrow (3:5); from the side of the Pharisees, a desire to condemn Jesus (3:2), hostile silence (3:4), hardness of heart (3:5), and the instigation of a murder plot (3:6). It is symptomatic of the difference between 3:1-6 and 2:1-12 that the latter begins and ends with reference to hostile opponents (Dewey 1980:104). Typically for a miracle story, there is no acclamation of the miracle from the audience; instead its Pharisaic observers go out and begin to plot Jesus' murder (cf. John 11:45-54; Marcus 2000:250). Corresponding to this emphasis on conflict, the man who is healed plays a relatively minor role in the story, serving primarily as a spotlight to focus the attention on the tension between Jesus and the Jewish religious leaders (Guelich 1989:133).

\section{EXEGETICAL PERSPECTIVE ON THE HARDENING}

This controversial story (3:1-6) indicates that when Jesus entered

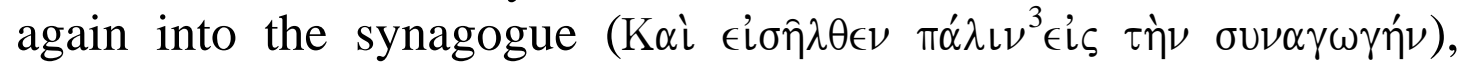

3 In Mark, $\pi \alpha$ $\lambda \iota \nu$ is used with two meanings: 'back' or 'again, once more'. This word in the report of Jesus' journey, is used with the second meaning, i.e., it is used when such an action is repeated. Mark uses this word when Jesus again visits a place, which he has previously visited (com. 2:1 with 1:21, 2:13 with $1: 16-20$, $3: 1$ with $1: 21$, $4: 1$ with $2: 13$, 5:21 with $4: 36$, $7: 31$ with $7: 24$, $11: 27$ with $11: 7,15)$. The word $\pi \alpha \dot{\alpha} \lambda \iota \nu$ calls the reader's attention to a previous place or action. Hence, the word in 3:1 ("he entered again into a synagogue”) 
there was a man with a withered hand (v. 1b), and Jesus' activity being was monitored by Jewish leaders in an attempt to catch him in an act of breaking the Sabbath Law (v. 2). As the narrator intentionally uses the word $\pi \alpha \dot{\lambda} \iota \nu$, he intends to establish a connection with a place Jesus has already been in (Mark 1), in this case a synagogue (1:21; Lane 1974:133). In Mark's Gospel, Jesus' first teaching and miracle, which was to heal a man who was possessed by an evil spirit, occurred in a synagogue of Capernaum (1:21-28). In response to Jesus' ministry, the people were generally amazed, but the parties concerned with the synagogue, i.e., the Scribes and Pharisees (cf. 2:6, 16, 24; 3:6) were silent. They refused to believe in Jesus as Son of God through silent criticism (cf. 3:4). Hence, Mark, in the fifth controversial story, does not simply echo the incident: he draws a conclusion about the opponents' unbelief and rejection of Jesus, which perhaps began in 1:21-28 and has escalated through other controversy stories.

\section{The unbelieving “watching” in Mark 3:2}

Furthermore, the opponents demonstrated their unbelief of Jesus; "they were watching ( $\left.\pi \alpha \rho \epsilon \eta^{\prime} \rho v_{\nu}\right)$ closely"(3:2) ${ }^{4}$. The word $\pi \alpha \rho \epsilon \tau$ ๆ $\rho$ ouv has no expressed subject (as in 2:18), but the preceding passage and the specification that it was the Pharisees and Herodians (3:6) against Jesus, indicates that the nucleus of the hostile attention was Pharisaic, even though the whole congregation was aware of the tension of the situation (France 2002:149). If we see this story as a sequel to the Capernaum synagogue episode (cf. 1:21 and 3:1) and to the story found at the end of Mark 2, then Dewy is most probably correct in saying that we may see 2:24 as the caution before actual legal trial on an accusation that would be set in motion; and at 3:2 the adversaries are observing so that if Jesus acts illegally again on the Sabbath, he is liable to be arrested (Dewey 1980:99-100). "The

could be a reminder of Jesus' first entrance into the synagogue of Capernaum in $1: 21$.

4 "There is no subject expressed here, but it is easily supplied from our knowledge of the class who insisted on these rigors of Sabbath observance. And 3:6 tells us that it was the Pharisees who went out and conspired with the Herodians against him" (Gould 1975:52). The Pharisees appear always in Mark as antagonists $(2: 16,18,24 ; 3: 6 ; 7: 3 ; 8: 11,15 ; 10: 2 ; 12: 13)$. Jesus called them "hypocrites" (7:6), refuses to grant their request for a sign (8:11), and warns his disciples against the "leaven of the Pharisees" (8:15). 
claim of Jesus in 2:28 prepares the reader for the higher level of hostility and greater stakes involved in 3:1-6” (Dewey 1980:100).

The imperfect tense of $\pi \alpha \rho \epsilon \tau$ p $\rho$ ouv is probably iterative: they kept on watching (Brooks 1991:68). Apparently, the meaning is not that Jesus was watched by the common people, but has kept under surveillance by his antagonists. What the Pharisees are trying to find is legal evidence for accusing Jesus. This implies that they refuse to believe in Jesus' claim that he is the Lord of the Sabbath and Son of God. This same verb is used in Psalm 36:12 (one of only two LXX usages), in which it is the sinner who lies in wait for the pious, to slay him (cf. Ps. 129:3; Marcus 2000:252). This is similar to the account of the Pharisees' plot at the end of our passage (3:6). They wish to accuse him, that is, bring legal charges against him because the violation of the Sabbath would be a serious offence and could be punishable by death (Ex. 31:14-15; M. Sanhedrin 7:4).

It is important to note that Mark's explanation suggests that the real issue is not whether or not the Sabbath should be kept, but how it should be kept. Throughout his Gospel, Mark portrays Jesus as faithful upholder of the Torah (1:44; 3:4; 7:8-13; 10:3-9; 12:29-31), who attacks not the Torah itself, but the interpretation given to its demands by the religious leaders of his day (Hooker 1991:106). It is not, then, the Torah which is at fault but those who misinterpret it; the purpose is to bring life, but when it is wrongly applied, it could become an instrument of evil and the bearer of death ${ }^{5}$.

\section{The unbelieving silence in Mark 3:4}

Although the reader is not told explicitly as he was in 2:8, that Jesus is aware of the silent question of the Pharisees, i.e., violation of the Sabbath (Dewey 1980:102), the question is answered by Jesus' ironic double counter-questions, as in 2:23-26 (Taylor 1966:222). Before the questions, Jesus commands the man with the shriveled hand "stand up ${ }^{6}$ in front of everyone" $(3: 3)^{7}$. Then, he poses the

5 Com. Rom. 7.

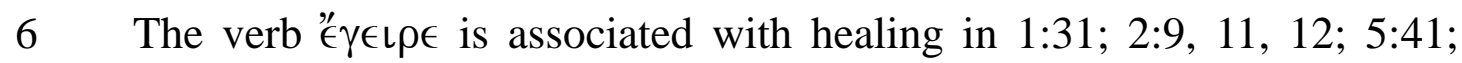
10:49; 16:6, and carries overtones of the restoration of health and even of life itself (resurrection; Donahue \& Harrington 2002:115). Mark's reader may well have been aware of this insinuation of the verb, which proposes that the man is being offered new life (Hooker 1991:87). 
question: which is lawful, to preserve life by healing or to destroy life by refusing to heal on the Sabbath? (3:4). It was not normally permissible to heal on the Sabbath, since healing was classified as work but, if life was threatened, then emergency treatment was allowed (Edwards 2002:99). It is to this principle that Jesus appeals and which he extends, because in this case the man's life is not in danger (France 2002:149). In describing a sharp converse between doing good and doing evil and between attitudes which either save life or kill, Jesus refuses to describe a distinction between saving life in the narrowest sense and the offer of full life, which characterizes his whole ministry (Hooker 1991:107). To postpone healing for a day is to disagree with the Sabbath's true intention, which is the glory of God and the benefit of man. Through their negligence of opportunities to do good things, the Pharisees destroyed life rather than saved it and in so doing, did much harm. While Jesus was ready to heal, the Pharisees were plotting to put him to death. It is obvious who really was guilty of breaking the Sabbath (3:4a), but they refused to answer the question and remained silent (3:4b).

This silence does not reflect, "The casuistic persuasiveness of Jesus' answer” (3:4; Guelich 1989:137). The opponents' silence and subsequent response (cf. 3:6) indicate "their perception of a much deeper issue that challenged far more than their interpretation of the Law” (Guelich 1989:137). The Pharisees can neither deny their principle of saving life on the Sabbath nor go along with Jesus' new principle.

\section{The portrayal of the hardness of heart in Mark 3:5}

The Pharisees said nothing, being incapable of response, because of their hardness of heart. Jesus' reaction to the silent Pharisees is narrated in 3:5a, which illustrates Jesus' anger and grief ${ }^{8}$ over the

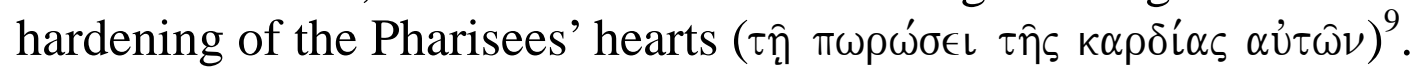

7 Accord to Derrett (1984:172), a withered hand is frequently the punishment for stretching out one's hand to reach for something sinful (Ps. 137:5; Zech 11:17). Jeroboam's hand "dried up" when he tried to take action against the rebellion prophets (1 Kings 13:4-6). His condition would have been regarded as proof of un-confessed sin that had not escaped God's notice (Ps. 32:1-5).

8 'Anger' used here and in the verbal from in $1: 41$, is virtually synonymous with 'wrath' (cf. Isa. 63:3, 6; Rom 2:8; Col 3:8). When used by humans, anger and wrath are vices (Gal 5:20; Col 3:8; Eph. 4:31). The wrath of 
The hardening of the Jewish religious leaders indicates not only that the Jewish religious leaders did not, as a matter of course, understand Jesus' true significance, but that they could not understand it (Heil 1981:74). The biblical motif of 'hardness of heart' signifies human resistance to God's revelation. The concept carries with it a mixture of divine and human responsibility. "The hardening by God is also a self-hardening of the unbeliever who does not obey God. Though in this mystery man cannot escape the sovereignty of the divine action, this does not absolve him from personal responsibility" (Schmidt 1965:1026). The Jewish religious leaders who refuse to believe in Jesus and kill him act on their own volition (3:6; 12:12; 14:1-2; 15:1). The Jewish religious leaders' hardness of heart (3:5) was caused not by withholding instruction but by their own unwillingness to receive it. Their hardness of heart was the basis for rejecting him, not the result of his rejection of them (Geddert 1989:74). In the parable in 12:1-10 the wicked tenants intentionally kill the owner's son in order to seize the inheritance (12:7).

In the parable of the Sower (4:1-10), the negative fates of the seeds are an allegorical allusion to people who fail to believe in Jesus throughout Mark's Gospel (Tolbert 1989:151-60). The first ground on which the seed is sown is that of the path. The earth is so hard that the seed stays on the surface and rejects its fruitfulness. Similarly, from first to last the opponents refuse to accept Jesus' healings and forgiving words and to believe in him. Instead they kill him. The language highlights the inability to understand divine revelation. Rather than upsetting God's redemptive plan, the 'hardness of heart' is part of it.

God describes God's displeasure at human evil, every often as a summons to change or reform (Deut 9:7, 8, 22; Isa. 60:10; Pss 6:1; 38:1), and with reference to the disclosure of divine wrath that will characterize the eschatological day of the Lord (Zch 1:15; Mt 3:7; Lk 3:7; Donahue and Harrington 2002:116).

9 In the Greek literature, the 'tuff-stone' derived from o $\pi \hat{\omega}$ pos was used medically in order to describe "the hardened swelling of the bone" (Aristotle

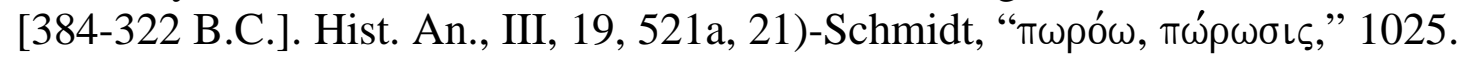
Hippocrates (460-377 B. C.?) transferred it to mean "to make dull or insensitive" physically or mentally (Nymphis Fr., 16 [FHG, III 16])-Schmidt,

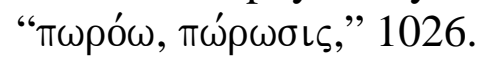


On the other hand, in Isaiah 6:9-10 alluded in Mark 4:12 God, through the prophet, hardens the hearts of those who do not repent of their sins. Unless the opponents repent of their sins and believe in Jesus, God, through the parabolic words, hardens their hearts so that they do not understand the secret of the Kingdom and do not believe in his teachings and works. "That the evangelist seems to be saying that it was God's will that few believe in Jesus because of hardened hearts seems to be unavoidable" (Tolbert 1989:151-60).

At the end of this story, the Pharisees and Herodians ${ }^{10}$ began to plot against Jesus looking for a way to kill him (3:6). It is perhaps

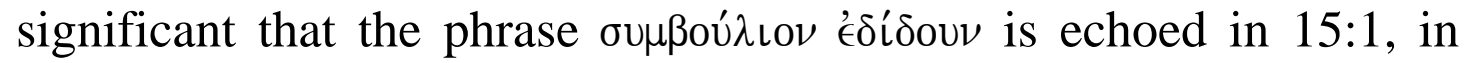
which $\sigma u \mu \beta o u ́ \lambda\llcorner o v$ occurs again, either in the sense of 'decision,' or with the meaning of 'consultation'. The verb $\alpha \pi 0 \lambda \lambda u \mu \iota$ is picked up again in 11:18, in which it is the chief priests and Scribes who plot Jesus' death. Their pact to destroy him will conclude in 15:1, when another group of power brokers take council to destroy him successfully, or so they think (Ps 37:31-33; Isa. 29:20-21; Jer. 20:1011; Garland 1996:109). Thus, the reader is enabled to put more substance into Jesus' enigmatic hint about the 'removal' of the bridegroom (2:20), and to envisage more concretely the two contrasting reactions to Jesus which will form the framework for the narrative and discourse of chapter 3-4, the rejoicing of the wedding guests and the plotting of those who are determined to destroy the bridegroom (France 2002:153; Edwards 2002:102).

\section{Pharaoh's hardness of heart}

The use of the phrase of "hardness of heart" in Mark's Gospel echoes the OT texts, and this provokes a question, whether this OT usage had an influence on Mark's story or not. The most famous biblical example of "hardness of heart"11 is the Pharaoh of Exodus

10 They were the supporters of Herod Antipas (Josephus, J.W. 1.16.6 § 319; Ant. 14.15.10 § 450), who had arrested John and eventually beheaded him.

11 In the OT, the word "heart" (לב) has a dominant metaphorical use in reference to the centre of human psychical and spiritual life, to the entire inner life of a person (Luc 1997:749). "The heart is the seat of emotion, whether of joy (Deut 19:6; 1 Sam 2:1) or pain (Jer 4:19), of tranquility (Prov. 14:30) or enthusiasm (Deut. 28:47), etc; man's creative and wicked thoughts are attributed to the heart” (2 Sam 18:32; Gen 6:5; Fabry 1994:414). Furthermore, planning and volition are attributed to the heart; a decision may be described as 'setting' the heart (2 Chr. 12:14); removal of the decision-making ability is 
(Ex. 7:3, 13, 22; 8:15). According to Marcus, "Mark intends his readers to link the Pharisees with the Egyptian king, especially since the Greek words, $\Phi \alpha \rho\llcorner\sigma \alpha \hat{\imath}$ os and $\Phi \alpha \rho \alpha \hat{\omega}$, are so close to each other" (Marcus 2000:253).

Pharaoh had begun hardening his own heart long before God stepped in. Pharaoh was cruel and evil, he delighted in exploiting the people of Israel for profit (Ex. 1:14; 2:23; 3:7, 9) and had no respect for the One true God (Ex. 5:2). He not only flatly refused to listen to Moses and Aaron when they first came to him, but he also used their appeal as justification to treat the Israelites more cruelly than before (Ex. 5:5-18).

God, who knows the hearts of all men (Jer. 17:10), knew that Pharaoh would not listen to Moses and Aaron except under extreme compulsion. He predicted this to Moses (Ex. 3:19; Chisholm 1996: 411-12), and indeed, the first six times that Moses and Aaron came to Pharaoh, the writer says that Pharaoh's heart was hardened, or that he "hardened his heart" (Ex. 7:13, 7:22; 8:15; 8:19; 8:32; 9:7). Pharaoh had seen many miracles, but was not prepared to let the Israelites go. He made it clear in the sight of God and Moses that he had set himself in rebellion against the Lord (Greenberg 1967:156). Pharaoh indicated numerous times that he was determined to harden his heart. There came a point where God said, in effect, "Very well, if you want to harden your heart continually, then I'm going to let you harden your heart” (cf. Ex. 4:21; 7:3; 9:12; 10:1, 20, 27, 11:10; 14:4, 8, 17; Eichrodt 1967a:191).

Despite the many plagues brought against him through Moses, Pharaoh (or God) hardened his heart (Ex. 4:21; 7:3, 13, 14, 22; 8:15, 19, 32, 35; 9:7, 12, 34; 10:1, 20, 27, 11:10; 14:4, 8, 17) and refused to believe in God's work in Moses and to allow the Israelites to leave

depicted as 'hardness of heart' (Ex. 10:1; Josh. 11:20). The heart demonstrates spiritual activity through which people determine their religious and ethical relationship to God (Eichrodt 1967:142-44; e.g. Deut 5:29; 29:4; 1 Sam 16:7; Prov 4:23; 5:12; 6:21; Ezek 11:10; 36:26; Joel 2:13). The heart combines these faculties - the emotional, intellectual, volitional - rather than isolates them. Consequently, the heart in the OT is often seen as the inner and spiritual totality of a person's relationship to God. When the heart is often hardened, made obdurate, made fat, people become insensitive and unwilling to act, and they are no longer able to believe and obey God's call and command. 
Egypt $^{12}$. Yet, the continued hardenings, disbelieving, and refusals provoked great acts of judgment, such as the tenth plague $(7: 4)^{13}$. During which God destroyed the firstborn sons of Pharaoh and the Egyptians just as they were seeking to destroy God's firstborn, i.e. Israel (cf. 4:22-24; Willson 1979: 18-35). This sounds very much like the law of 'tooth for tooth', i.e. an act of judgment or punishment in retribution. What is more, in Ex. 15 as Moses praises God for his deliverance, God is cast in the role of the Israelites' champion who destroys their enemies - those who oppose God. They experience his 'burning anger' (vs. 6-7).

Although some Exodus texts (Ex. 4:21; 7:3; 9:12; 10:1, 20, 27, $11: 10 ; 14: 4,8,17)$ relate the fact that Pharaoh's heart is hardened by the Lord, and Paul emphasizes God's sovereign right to dispose of human affairs as he pleases (Rom. 9:14-18), Mark's narrative emphasizes the Pharisees' responsibility for their attitude (Mk. 3:5-6; Beavis 1989:89-90). This is illustrated by the 'inside view' the writer gives the reader/audience of Jesus' emotional reaction to the Pharisees' question: he is 'angered' and 'grieved' at their hardened hearts (3:5; Hurtado 1989:40). The implication is that better behavior might be expected from the Jewish religious leaders, not that God has predestined that they act unmercifully.

\section{Pharaoh's hardening in the Jewish literature}

The author of Wisdom of Ben Sira, in Sirach 16:15-16 ${ }^{14}$, quotes the 'hardness of heart of Pharaoh' as an instance to illustrating God's righteous wrath against the wicked, "the Lord hardened the heart of Pharaoh who knew Him not, whose works were manifest under the heaven" (Sir 16:15). God judges the Wicked Pharaoh, because of his hardness of heart. In Antiquities II, Josephus retells the Exodus narrative. In his writing, Josephus does not use the term "Pharaoh's hardness of heart”. Instead, he interprets the hardening attitude as the

12 Just as we investigated in the previous section, the unbelief of Jesus' opponents implied the refusal to understand and obey Jesus' prophetic messages and miracles.

13 In relation to the phrase in verse 21 "I will kill the firstborn in Egypt", we can assume that "these great acts of judgment" constitute the tenth plague.

14 "Verses 15-16 (in the footnote) appear in one Hebrew manuscript and a few witnesses in Greek and Syriac. Verse 15 was added by a copyist who felt Pharaoh should have been included among the sinners who were destroyed, and verse 16 introduces a reference to God's mercy in creation” (Snaith 1974:83). 
characteristic of the wicked (Ant. II. XVI. 5; cf. Sir 16:15; Rom 9; Stone 1977:345).

In De vita Mosis I, Philo recounts that Pharaoh and the Egyptians whose hearts are hardened are described as the wicked, the foolish men and the impious $(95,96)$. Moses asks Pharaoh and the Egyptians to send the Israelites from Egypt. However, these impious men refuse it, "clinging to their original inhumanity and impiety as to some inalienable virtue" (95; Yonge 1993:468). After they partially recovered from these punishments, they again return to their original wickedness and forget the evils that they have already experienced $(102,106,120)$. Thus, ten punishments are inflicted upon the land so that it is destroyed. The purpose was to exhibit the height of the authority that God wields (96).

In early Jewish sources, the concept 'hardness of heart' qualified the wicked, like Pharaoh and the Egyptians. Due to the hardness of heart, they did not believe in God and obeyed his commands. The consequent result was Gods' judgment. In the materials of early Jewish writers (Josephus and Philo), the hardening of the wicked is used as an instance to illustrate God' righteous wrath and to warn the righteous against disobedience. Consequently, Pharaoh's hardness of heart was consequently used as an example on behalf of the wickedness and unbelievers. However, when used for the covenanters and the righteous, it fulfilled the function of warning and exhortation to deter them from disobedience.

The use of Pharaoh's hardening in early Jewish literature provides the appropriate context for properly assessing the function of its echo in Mark 3:1-6. Mark takes an idea known broadly in the Jewish context in the first century A.D., in order to describe the Jewish religious leaders' unbelieving rejection. Just as Pharaoh had refused to believe and obey God's message because of his hardened heart, so also the Jewish religious leaders did not believe in Jesus as the Son of God due to their hardness of heart, rather rejected him. It is for this reason that God would judge them, because of their persistent unbelief, due to their hardness of heart (Marcus 2000:253).

The opponents' unbelief is illustrated by the language 'hardness of heart' $(3: 5 ; 10: 5$; cf. $6: 52 ; 8: 17-18)$, which sums up the people's opposition to the power of God at work in Jesus. Due to their hardened hearts, the opponents have not believed that the Sabbath is for the refreshment and restoration of humanity, nor did 
they accept that Jesus is bringing in the eschatological Sabbath conditions, when there will be ongoing relief from death (3:5-6). Their plot, which is caused by their hardened hearts, is repeated (11:18; 12:9) and expanded in the following way: seizing, beating, striking, and killing him (12:1-12). Accordingly, the opponents' hardness will cause God to judge them. Even though the opponents know he has spoken the parable of the wicked tenants in 12:1-12 against them, they do not repent of their sins, but they continually reject Jesus (12:12; cf. 3:5-6), because their hearts are hardened. And they hand Jesus over to death. Therefore, the opponents who have rejected Jesus, the Son of God, will not escape from impending judgment. Their wilful rebellion necessarily excludes them from obtaining the forgiveness of God, and from the kingdom of God (cf. 3:29).

\section{THEOLOGICAL PERSPECTIVE ON THE HARDE- NING}

The verb $\pi \omega \rho$ ó $\omega$ means 'to harden a broken bone for healing'. The word is always used figuratively in the NT. If the $\kappa \alpha \rho \delta i \alpha \varsigma$, the seat of mental discernment and spiritual insight, is hardened, it cannot function properly to accept new insight (Robinson 1903:267-74). Jesus' critics are 'set in their ways', and in their insensitivity (or 'obdurate stupidity'). The phrase "hardness of heart" is almost a stock expression in the NT for those who cannot or will not perceive the truth. It is used most commonly with reference to Israel's failure to recognize Jesus as their Messiah (Rom. 11:7, 25; 2 Cor 3:14; Jn 12:40, citing Isa. 6:10). On two other occasions, it is used by Mark to describe the disciples' failure to appreciate the significance of Jesus’ miracles (6:53; 8:17; France 2002:151).

Mark considers "hardness of heart" as the highest cause of unbelief and an utter insensitivity to man's needs and problems. Throughout Mark's Gospel, refusal to believe in Jesus is described by this phrase (3:5; 10:5; cf. 6:52; 8:17-18), which sums up human opposition to the power of God at work in Jesus. Since their hearts were hardened, the Jewish religious leaders did not believe that the Sabbath is for the refreshment and restoration of humanity, nor did they accept that Jesus enriched the idea further with certain new eschatological Sabbatical conditions, teaching of a time when there will be ongoing relief from death (Witherington III 2001:134). As Mark recounts Jesus' anger and deep sorrow over the hardness of 
their hearts and their murderous plan, he wants the readers to avoid the way of the Jewish religious leaders.

Although the people had seen many instances of God's work revealed in Jesus' teachings and miracles, they did not want to accept it. They regarded it impossible to open up and accept the new principle in the kingdom of God. The reason is that they have shut down the possibility, through resisting the willingness and the ability to open up and think about what is going on. Human volition does not want to open up to what God wants to do, and does not want to realize that God is in Jesus' works (3:6; 12:1-10; 14:1-2; 15:1). Human volition wants a spectacular sign from God, or like the devil, a great display of divine power (Matt 4:1-11; Luke 4:1-13). However, it does not want God to become a human being, to be like one of us (cf. John 1:11; Edwards 2002:175).

Nevertheless, Satan stands behind human volition. In Jewish literature, the wicked who are ruled by the spirit of darkness (1QS 3:18-21) walk in the way of darkness with blindness of eyes, deafness of ears, stiffness of neck, and hardness of heart (1QS 4:11), so that they will never understand God's word. Hence, they will not escape from the imminent judgment (1QS 2:25-26; Dupont-Sommer 1976:82-83).

The depiction of the wicked in the Qumran texts is attributed quite similarly to those described as 'the one outside' in 4:12. In Mark's Gospel the outsiders are Jesus' opponents who have deliberately excluded themselves from the circle of salvation (the kingdom of God) by their attitudes of hostility toward Jesus (cf. 1:22, 39; 2:1-3:6; 7:1-23; 8:11-12 etc.; Marcus 2000:306). Similar to 1QS 3:18-21, in Mark 4:15 the opponents' refusal to understand Jesus' message of the Kingdom is the result of Satan-inspired opposition. In the parable of the sower, the first ground on which the seed is sown is that of the path. There the earth is so hard that the seed stays on the surface and birds come and eat it (4:4). Jesus interprets this action as Satan's coming to take away the Word (4:15). Since Satan prevented the opponents from listening to Jesus' message, they did not understand it, and rejected him and eventually brought about his death (3:6).

A theological perspective is one of the interesting elements in Mark's presentation. In Mark's Gospel "hardness of heart” is not simply Satan-inspired opposition, but God's will to procure salvation. 
In Jesus' predictions about his suffering and death (8:31; 8:14; $10: 33$; cf. $10: 45$; $14: 21,27$ ), the reality of the Jewish religious leaders' unbelieving rejection fits into God's will (14:36, 49). Jesus' predictions are exactly fulfilled in 14:61-55. Furthermore, in his death the Scriptures are being fulfilled $(9: 12 ; 14: 21,49)$. This no doubt refers to the fulfilment of the OT prediction of the death of the Son of $\mathrm{Man}^{15}$. In other words, it seems to be in accordance with God's plan that the Jewish religious leaders' hearts were hardened; they rejected Jesus and killed him. Although the hardness of heart is used to indicate people's incomprehension of Jesus and hostile action, the reality of hardness fits into God's purpose.

In Mark, "hardness of heart" is an instrument for the revelation of God himself in his redemptive history, as in Exodus in the case of Pharaoh's hardness of heart (Ex. 9:16; cf. Rom 9:17-18), in Mark's Gospel the Jewish religious leaders' hardness of heart is an instrument for the self-disclosure of Jesus as the Son of God (cf. 15:39). Because of their hardened hearts, they did not perceive Jesus' divine identity. Thus, they rejected him and killed him. But Jesus' death discloses his identity as the Son of God (15:37-39; cf. 1:1). The secret of Jesus' identity leads to his death (cf. 4:11-12), which, in turn, results in the open manifestation of his identity (cf. 4:22; Marcus 1986:147).

Hardness of heart is not without its redemptive elements, because it meaningfully advances the Markan Christology (Evans 1989:102-103). God, through the parabolic statements, hardens their hearts so that they did not understand the secret of the Kingdom (4:11-12). As a result, they refused to believe in Jesus' teachings and deeds, and handed him over to be put to death. That Mark seems to be saying that it was God's will that few believed in Jesus, because of hardened hearts, seems to be unavoidable. It seems to be God's redemptive plan that Jesus is rejected and handed over to be put to death by the hands of those whose hearts are hardened. "Without the hardened heart, Jesus would not have been rejected and put to death; and had he not been put to death, there could have been no resurrection and no Christian gospel: (Evans 1989: 103).

15 This death is indicated in a variety of passages such as Isaiah 53:3 and Psslm 41:9-13. 


\section{CONCLUSION}

Mark 3:1-6 recapitulates the first section of Jesus' Galilean ministry (1:16-3:6). Although Jesus proclaimed the arrival of the kingdom through his authoritative teachings and miracles, the Jewish leaders refused to respond to Jesus' message, because their hearts were hardened (3:5). Mark describes "hardness of heart" as the ultimate cause of the Jewish religious leaders' unbelief. Since their hearts are hardened, they did not believe in the truth that Jesus was introducing the eschatological Sabbath conditions, when there will be ongoing relief from death. Thus, with regard to the Jewish religious leaders the concept of "hardness of heart", the conscious refusal to believe in Jesus, delineated their unbelief and hostility.

Mark uses the motif of the unbeliever's hardness of heart to awaken his readers to repent of their unbelief and to follow Jesus with faith during the period of suffering. Thus, Mark forces the readers to distance themselves from their unbelieving attitude and align themselves with their blindness, deafness, and misunderstandding. He calls on the readers to respond differently by proclaiming the gospel about Jesus in spite of fear. In other words, the story of the unbeliever's hardening in Mark 3:1-6 encourages readers/hearers to become believers of Jesus' way - at least at a narrative level (Tolbert 1999:53).

\section{Consulted literature}

Beavis, Marry Ann 1989. Mark's Audience. The Literary and Social Setting of Mark 4:11-12. Sheffield: Sheffield Academic Press.

Brooks, James A 1991. Mark, The American Commentary Vol. 23. Nashville: Broadman Press.

Chisholm Jr, Robert B 1996. Divine Hardening in the Old Testament. Bibliotheca Sacra 153: 410-34

Derrett, J D M1984. Christ and the Power of Choice (Mark 3:1-6). Bib 65: 164179.

Dewey, J 1973. The Literary Structure of the Controversy Stories in Mark 2:13:6. JBL 92: 394-401.

-, 1980. Markan Public Debate: Literary Technique, Concentric Structure, and Theology in Mark 2:1-3:6. Chicago: Scholars Press.

Donahue, J H \& Harrington, D J 2002. The Gospel of Mark. Collegeville: The Liturgical Press.

Dupont-Sommer, A 1976. The Essene Writing from Qumran. Gloucester, Mass: Peter Smith. 
Edwards, J R 2002. The Gospel according to Mark. Grand Rapids: Eerdmans.

Eichrodt, W 1967a. The Theology of the Old Testament Vol. 1. Philadelphia: Westminster.

-, 1967b. The Theology of the Old Testament Vol. 2. Philadelphia: Westminster.

Evans, C A 1989. To See and Not Perceive: Isaiah 6:9-10 in Early Jewish and Christian Interpretation. Sheffield: JOST.

Fabry, H J 1994. לְ. TDOT Vol VII, 414.

France, R T 2002. The Gospel of Mark. A Commentary on the Greek Text. Grand Rapids: W. B. Eerdmans.

Garland, D E 1996. Mark. Grand Rapids: Zondervan Publishing House.

Geddert, T J 1989. Watchwords: Mark 13 in Markan Eschatology. Sheffield: Sheffield Academic Press.

Gould, E P 1975. The Gospel According to St Mark. The International Critical Commentary. Edinburgh: T \& T. Clark.

Greenberg, Moshe 1967. The Thematic Unity of Exodus 3-11. WCJS 1: 146-159.

Guelich, R A 1989. Mark 1-8:26. (WBC 34 A). Dallas: Word Books Publisher.

Heil, J P 1981. Jesus Walking on the Sea: Meaning and Gospel Function of Matt 14:22-33, Mark 6:45-52, and John 6:15b-21. Rome: Biblical Institute.

Hooker, M D 1991. The Gospel According to Saint Mark. Peabody: Hendrickson Publisher.

Hurtado, L W 1989. Mark. Peabody: Hendrickson Publisher.

Lane, W L 1974. The Gospel of Mark. Grand Rapids: W B Eerdmans.

Luc, Alex 1997. לי. NIDOTTE Vol 2, 749.

Mally, E J 1968. The Gospel According to Mark. Englewood Cliffs: PrenticeHall.

Marcus, J 1986. The Mystery of the Kingdom of God. Atlanta: Scholars Press.

-, 2000. Mark 1-8 (The Anchor Bible 27), New York: Doubleday.

Rhoads, D \& Michie, D 1999. Mark as Story: An Introduction to the Narrative of a Gospel. Philadelphia: Fortress Press.

Robinson, J A 1903. St Paul's Epistle to the Ephesians. London: Macmillan \& Co, Limited.

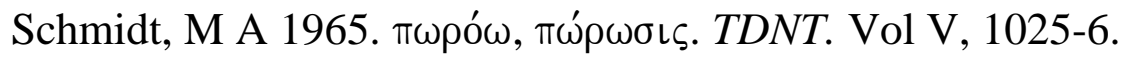

Snaith, John G 1974. Ecclesiastics, the Wisdom of Jesus Son of Sirach. Cambridge: Cambridge University Press.

Stone, R C 1977. Josephus. In Tenney, M C (ed), The Zondervan Pictorial Encyclopedia of the Bible Volume 3. Grand Rapids: Zondervan Publishing House.

Taylor, V 1966. The Gospel According to St Mark. London: Macmillan.

Tolbert, M A 1989. Sowing the Gospel: Mark's World in Literary-Historical Perspective. Minneapolis: Fortress Press. 
-, 1999. The Gospel of Mark. in Powell, Mark Allan (ed), The New Testament Today, 38-67. Louisville: John Knox Press.

Via, D O 1975. Kerygma and Comedy in the New Testament: A Structuralist Approach to Hermeneutic. Philadelphia: Fortress.

Willson, R R 1979. The Hardening of Pharaoh’s Heart. CBQ 41, 18-35.

Witherington III, B 2001. The Gospel of Mark: A Socio-Rhetorical Commentary. Grand Rapids: Eerdmans.

Yonge, C D (trans) 1993.The Works of Philo. Peabody: Hendrickson Publisher. 